\title{
KÖKÉNDY ÁKOS
}

\section{Néhány példa a számítási felhő használatára az iskolai szervezésben}

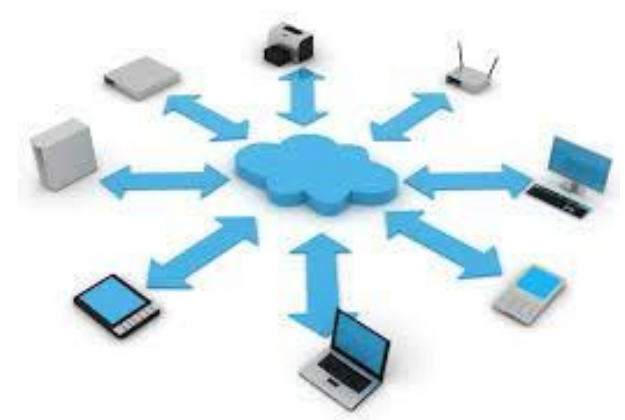

A felhő alapú számítástechnika az angol cloud computing kifejezés magyar fordítása. Olyan szolgáltatások gyüjtőfogalma, melynek használata során az adott szolgáltatás nem egy meghatározott, dedikált hardveren zajlik, hanem a szolgáltató hardverein elosztva. Az alábbi egyszerü példa világossá teheti, hogy mi a különbség a hagyományos szoftverek és a felhő alapú szolgáltatások között.

A Microsoft ${ }^{\circledR}$ Word ${ }^{\circledR}$ szövegszerkesztő szoftverrel nagyon sokan dolgoznak. Ez a szoftver a felhasználó számítógépére telepített, az általa elkészített fájlok is a gépen vannak. Minden lokális, egy dedikált hardver és egy dedikált szoftver teszi lehetővé, hogy a szöveget megalkossuk. Ha bemegyek a munkahelyemre, az ottani számítógépen nem fogom megtalálni az általam otthon írt anyagot.

Az egyetemi szakdolgozatom ezzel szemben a Google Drive Dokumentumok nevü szolgáltatásával készült. Ehhez nem kellett szövegszerkesztőt telepíteni, elegendő volt az operációs rendszer internet böngészőjét elindítani, a felhasználói fiókommal bejelentkezni és már indulhatott is a szöveg alkotása. Három különböző operációs rendszeren (Windows ${ }^{\circledR}$, Ubuntu linux, Android), különböző böngészők használatával, legalább hét különböző eszközön (asztali számítógépek, laptopok, telefon, táblagép) dolgoztam. A fájlt nem kellett magammal vinnem sehova, mindenhol jelen volt, ahol internet hozzáférésem volt. Nem léteztek különböző verziók, mindig az aktuális állapotot láttam, azt fejlesztettem.

A felhő alapú szolgáltatások esetében a fejlesztéseknek sokkal nagyobb hatása van a felhasználókra, mint a hagyományos szoftvereknél. Elképzelhető, hogy az otthoni gépünkön egy tíz évvel ezelőtt piacra dobott operációs rendszeren egy szintén tíz évvel ezelött megvásárolt szövegszerkesztő fut, a szoftverfrissítések csak biztonsági frissítések, nem befolyásolják a használatot. A felhő alapú rendszernél azonban azt tapasztalhatjuk, hogy minden további nélkül megváltozhat a kinézet, új lehetőségek jelennek meg, mások eltűnnek, vagy új helyre kerülnek, mindez annak érdekében, hogy a felhasználói élmény és a szolgáltatás minél tökéletesebb legyen.

\section{Néhány példa}

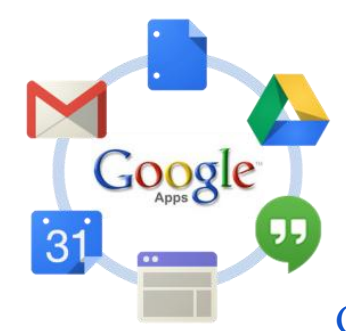

Google Apps Iskoláknak

A Google az internetes kereső szolgáltatásával lett világhírü. A cég által 2004-ben elindított 
Gmail nevü email szolgáltatást a 2012. éves adatok szerint 425 millió felhasználó használja. A webes email mellé kiépített ökoszisztéma az átlagos felhasználók számos igényét elégíti ki ingyen. A vállaltok számára kínált szolgáltatások ennél többre is képesek. Az iskolák számára ingyen elérhető vállalati rendszer szinte teljeskörü informatikai megoldást kínál az iskolák számára. Ez indokolja, hogy ezt mutatom be először. A bevezetését ráadásul megkönnyíti az a tény is, hogy nagyon sok tanár használja a Gmail szolgáltatásait magán célokra, így a felhasználói felület és a funkciók (legalábbis egy részük) ismertek elöttük.

A Google Apps Iskoláknak csomag magában foglalja a következő alapszolgáltatásokat:

E-mail

Drive

Naptár

Webhelyek

Osztályterem

Csoportok

Címtár

Google+

Hangouts

A Google Apps Iskoláknak egyik legnagyobb előnye, hogy az egyes szolgáltatások egymással integráltan, egymásra hivatkozva vannak jelen, így nagyon komplex feladatokat lehet elvégezni velük. Minden iskolai polgár kaphat felhasználói fiókot, melynek segítségével a saját alkalmazásaihoz hozzáfér.

Az e-mail bemutatása 2014-ben felesleges, mindenki naponta áldja és átkozza a munkaszervezés és információ áramlás ezen hatékony eszközét.

A Google Drive egy online dokumentumkezelő és -létrehozó szolgáltatás. Segítségével külön szoftver telepítése nélkül hozhatunk létre szöveges dokumentumokat, táblázatokat, prezentációkat, ürlapokat. Ezek a fájlok a távoli szerveren találhatók, böngészőből létrehozhatók és szerkeszthetők.

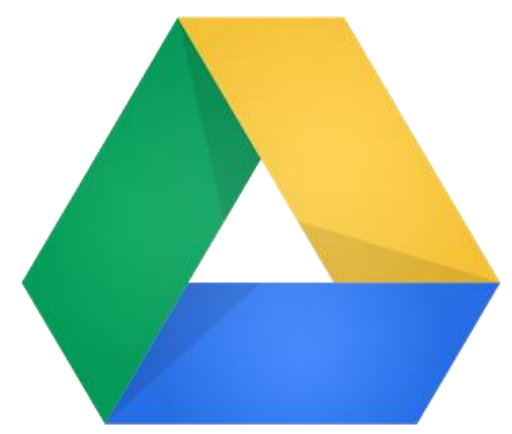

A rendszer nagyszerü tulajdonsága abban áll, hogy a létrehozott vagy feltöltött dokumentumokat könnyen megoszthatjuk munkatársainkkal vagy a diákokkal. Az online létrehozott dokumentumokat valós idöben többen is szerkeszthetik, az egyes szerzők különböző színű kurzorokkal vannak jelen a szerkesztői nézetben. Ez a lehetőség kizárja azt, hogy egy dokumentumnak különböző változatai keringjenek a szerkesztők és lektorok között, mindenki a legfrissebb állapotot láthatja és abban dolgozik. 


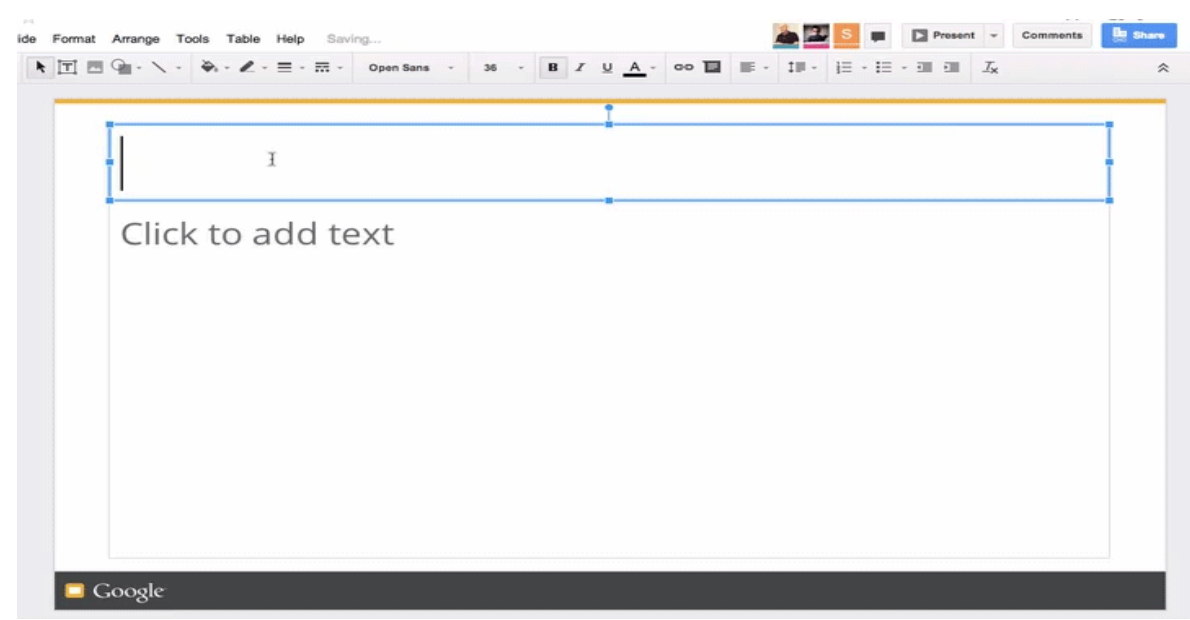

A Drive emellett fájltárolóként is müködhet. A megfelelö segédprogram letöltésével a számítógép mapparendszerében megjelenik egy Google Drive nevü mappa, amibe bármit belehelyezve, az azonnal feltöltődik a Google szervereire és bármilyen böngészővel elérhetővé válik. Ez lehetőséget teremt arra is, hogy az otthoni gépünk és a munkahelyi gépünk között a fájlok szinkronban legyenek. Egy otthon megkezdett munkát a munkahelyen is befejezhetünk, vagy fordítva, miközben automatikus biztonsági mentés is készül minden fájlról. Minden felhasználó korlátlan tárhellyel rendelkezik!

A különböző szervezetek által leginkább igényelt szolgáltatások közé tartozik az online naptár vezetése. A tetszés szerinti szinten megosztott naptárakban nyomon lehet követni a vezetők elfoglaltságát, az egyes termek foglaltsági állapotát. A szervezeten belül nagyon fontos információk a fontosabb események részletei, melyeknek nyilvántartására ez a szolgáltatás tökéletesen megfelel. Az egyes felhasználók korlátlan számú naptárt hozhatnak létre, ezeket különböző célokra használva a különböző típusú elfoglaltságok könnyen megkülönböztethetők a naptári nézetben.

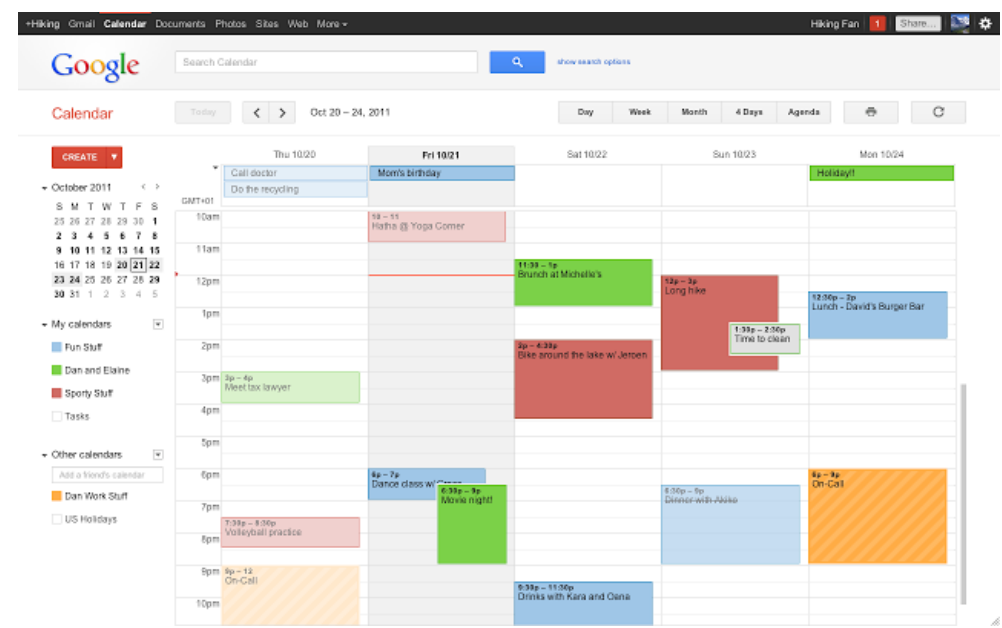

A webhelyek szolgáltatás egy intranetnek felel meg. Bárki létrehozhat tetszőleges célú és tartalmú honlapot, melyet különböző szinteken oszthat meg másokkal.

Az Osztályterem a csomag legfrissebb fejlesztése (2014 augusztusában indult), olyan virtuális tanulási környezetet ad a tanárok kezébe, ahol nagyon könnyü az egyes tanulói csoportok létrehozása, a kurzusok meghirdetése és az azokra történő jelentkezés. A kiadott feladatokat a tanárok és a diákok is egy nagyon egyszerü felületen kezelhetik, a határidők jól nyomon követhetők, a tanár minden egyes diáknak külön visszajelzést, értékelést adhat, az elért eredményeket exportálhatja. A fájlok az adott kurzus Drive mappájában találhatók. 


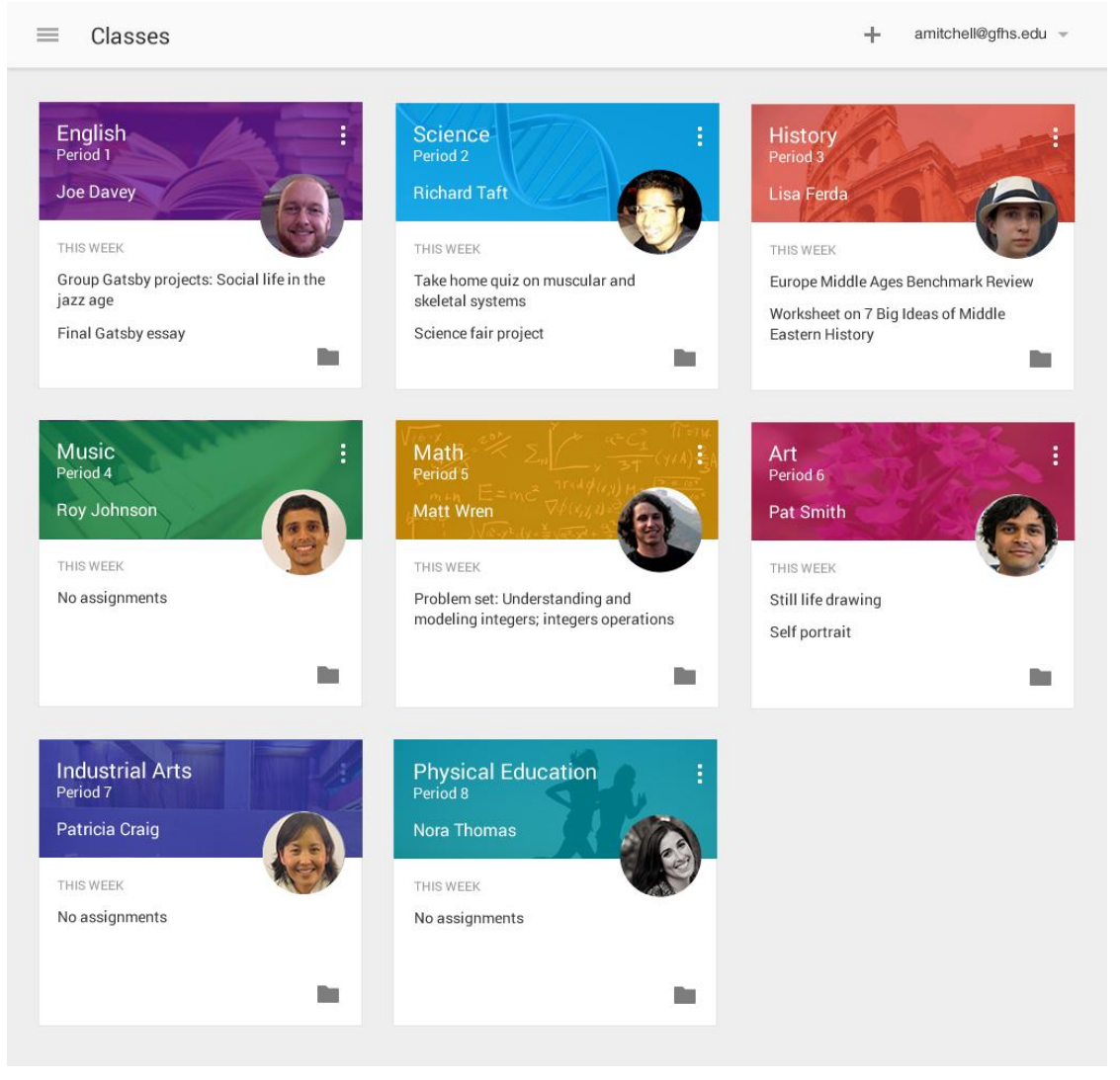

Az intézményi kommunikációk egyik legkönnyebben használható formája a levelezési csoportok létrehozása. Egy ilyen csoport létrehozása csak néhány percet igényel, föleg akkor indokolt ilyet indítani, ha a munkatársak egy csoportja rendszeresen kommunikál egymással. A csoportban megjelent levelek egy közös archívumból később visszakereshetők. Az iskola szülöi közösségével is lehet ilyen csoportos levelezést biztosítani, így a kiküldött levelet elég egyetlen csoport-címre elküldeni, mert azt a csoport összes tagja megkapja majd.

A címtár egy részét a szervezeti e-mail címek és az ezekhez tartozó névjegyek jelentik, de lehetöség van arra is, hogy a rendszergazda a címtárba feltöltsön olyan névjegyeket, melyekre sürün szükség lehet.

A Google+ a rendszerrel járó közösségi szolgáltatás, a Hangouts pedig a csevegő/videokonferencia szolgáltatás neve.

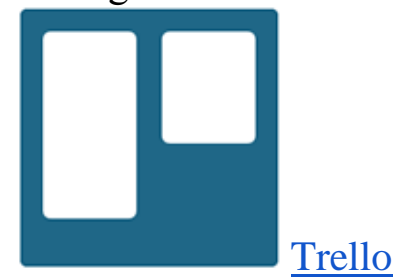

A Trello a feladatok, projektek figyelemmel követése, tervezése és dokumentálása szempontjából lehet nagy segítség az iskolában. Az online rendszerben minden feladathoz egy kártyát lehet rendelni, és ezeket a kártyákat lehet - a Post-it cédulákhoz hasonlóan - mozgatni egy táblán. A munkatáblákon különböző elnevezésü oszlopokba rendezve láthatjuk egy feladatkör kártyáit, ilyen lehet pl. az "Ötletek - Feladatok - Folyamatban - Kész" elrendezés. 


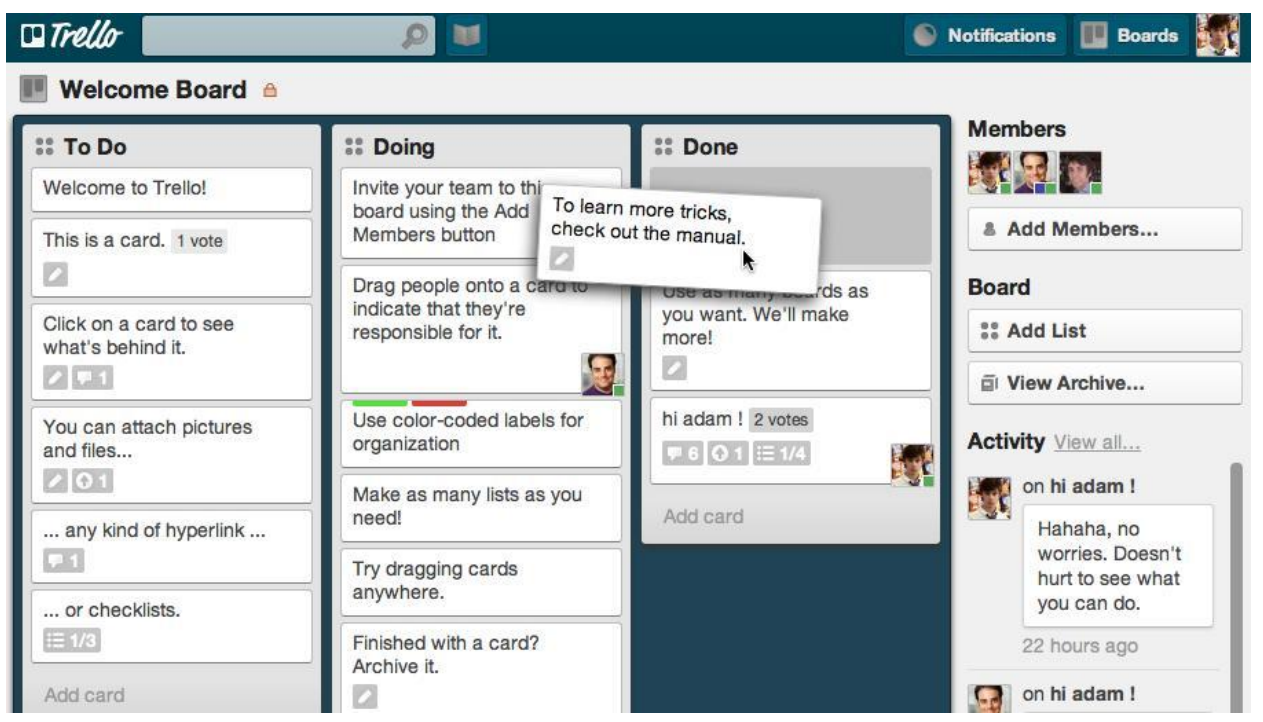

Egy nagyobb projekt során - mondjuk egy ünnepi eseménysorozat - a kezdetekben felmerült ötletekböl lehetnek a konkrét feladatok, melyek szervezése folyamatban lehet már, majd átkerül a Kész oszlopba. A képernyőn egyetlen pillantással láthatjuk az összes kártyát, azok fontossági sorrendjét, a határidőket és a felelösöket. Az egyes munkatáblákhoz ugyanis nem csak egy embernek lehet hozzáférése, hanem mindenkinek, aki az adott projektben részt vesz. Ha egy feladat több kisebb feladatból áll, akkor ehhez kiegészítő listákat lehet füzni, a feladatok előrehaladását megjegyzésekkel lehet dokumentálni, az egyes szükséges dokumentumokat (szerződések, plakát-tervek, programfüzet) a kártyákhoz lehet csatolni.

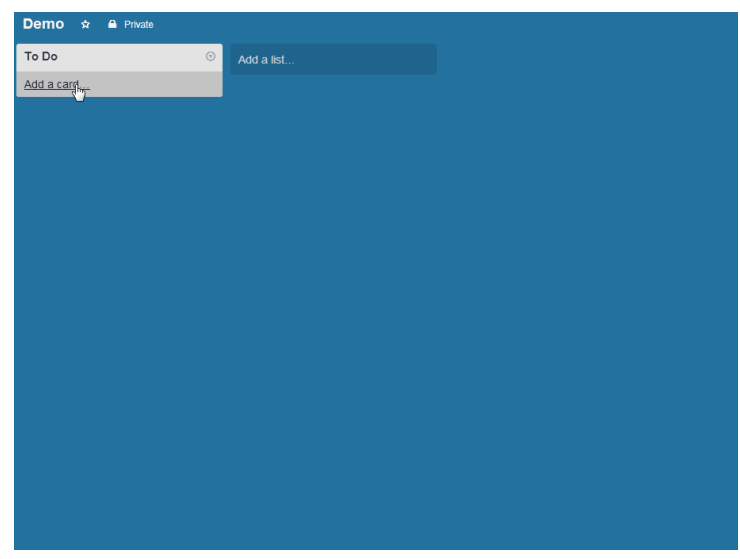

A Trello teljesen online, a böngészőből elérhető, nincs telepítendő szoftver, nincs helyben tárolt fájl. Az egyes részletek természetesen kinyomtathatók, tehát ha valaki papíron is látni szeretné mindazt, amit megalkotott a képernyő elött, az ezt is megteheti. A Trello határidőket egy új naptár formájában felvehetjük elektronikus naptárunkba, így minden más naptárbejegyzésünk között megtalálhatjuk ezeket a határidős feladatokat is.

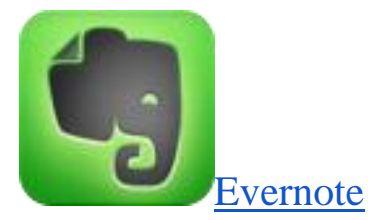

A szolgáltatást az alábbi módon lehetne röviden összefoglalni: készíts jegyzeteket, és érd el őket bárhonnan. Mivel itt is felhő alapú szolgáltatásról van szó, így a különböző eszközökön készített feljegyzések egyazon felhasználó jegyzetei között jelennek meg. Létrehozhatunk 
jegyzettömböket is, az egyes jegyzeteket címkékkel láthatjuk el, és a rendszer nagyon hatékony kereső funkcióval rendelkezik. Az alkalmazás nem csak számítógépekre, hanem okos telefonokra, táblagépekre is letölthető, a felhasználó azonosítása után bármely jegyzetünket azonnal elérhetjük az adott eszközröl.
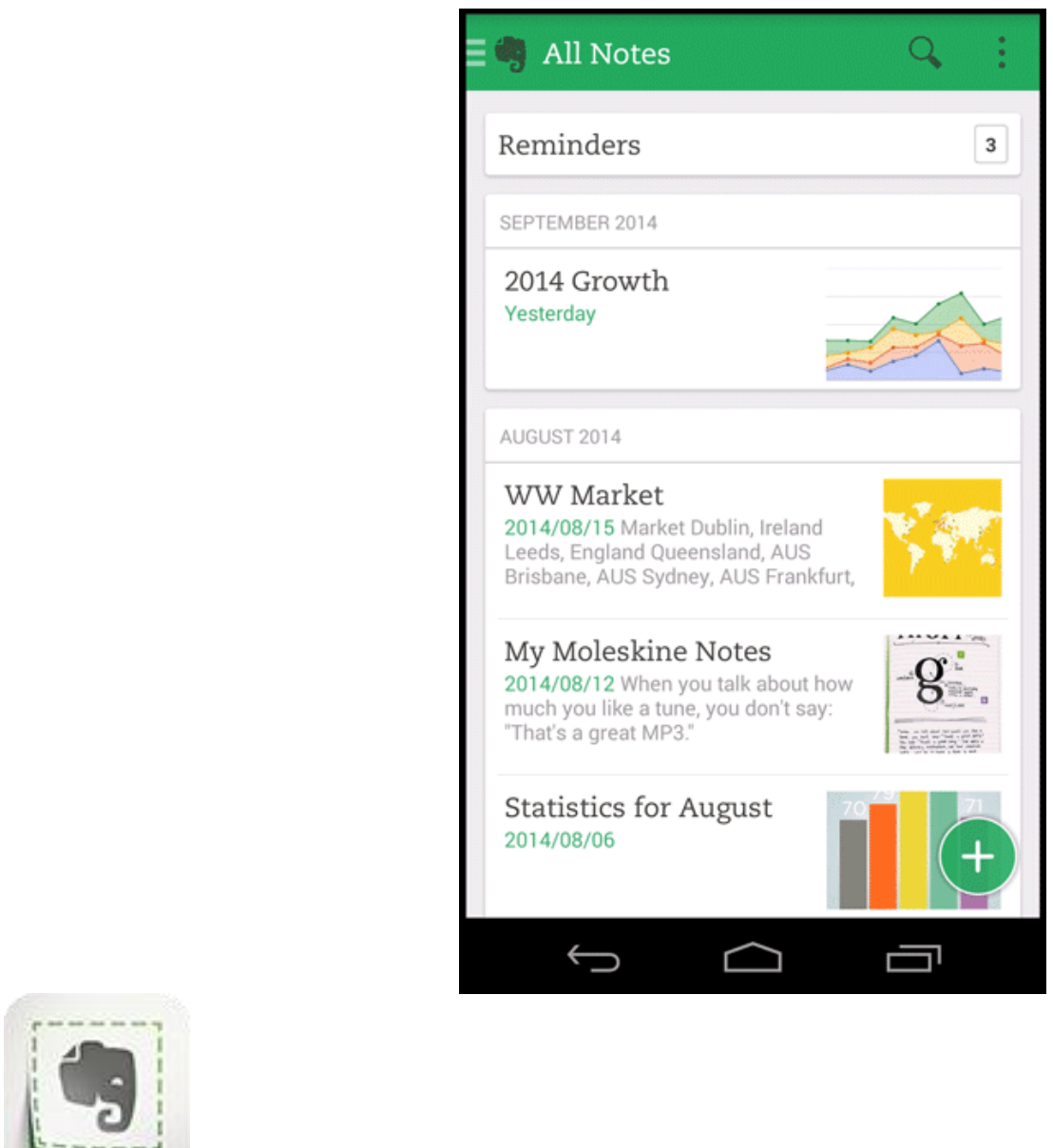

Az egyik leghasznosabb szolgáltatása az internetes kivágó szolgáltatás. Az Evernote kis beépülő modulja a böngészőbe épülve lehetővé teszi, hogy az interneten talált tetszőleges tartalmat azonnal elmentsük jegyzeteink közé, méghozzá az eredeti formában, de utólag tetszés szerint szerkeszthető változatban. A kivágott cikket vagy szövegrészletet úgy menti el, hogy a kivágáshoz hozzákapcsolja az eredeti hely URL címét, így a jegyzetből bármikor közvetlenül visszaugorhatunk a kivágás eredeti helyére. 


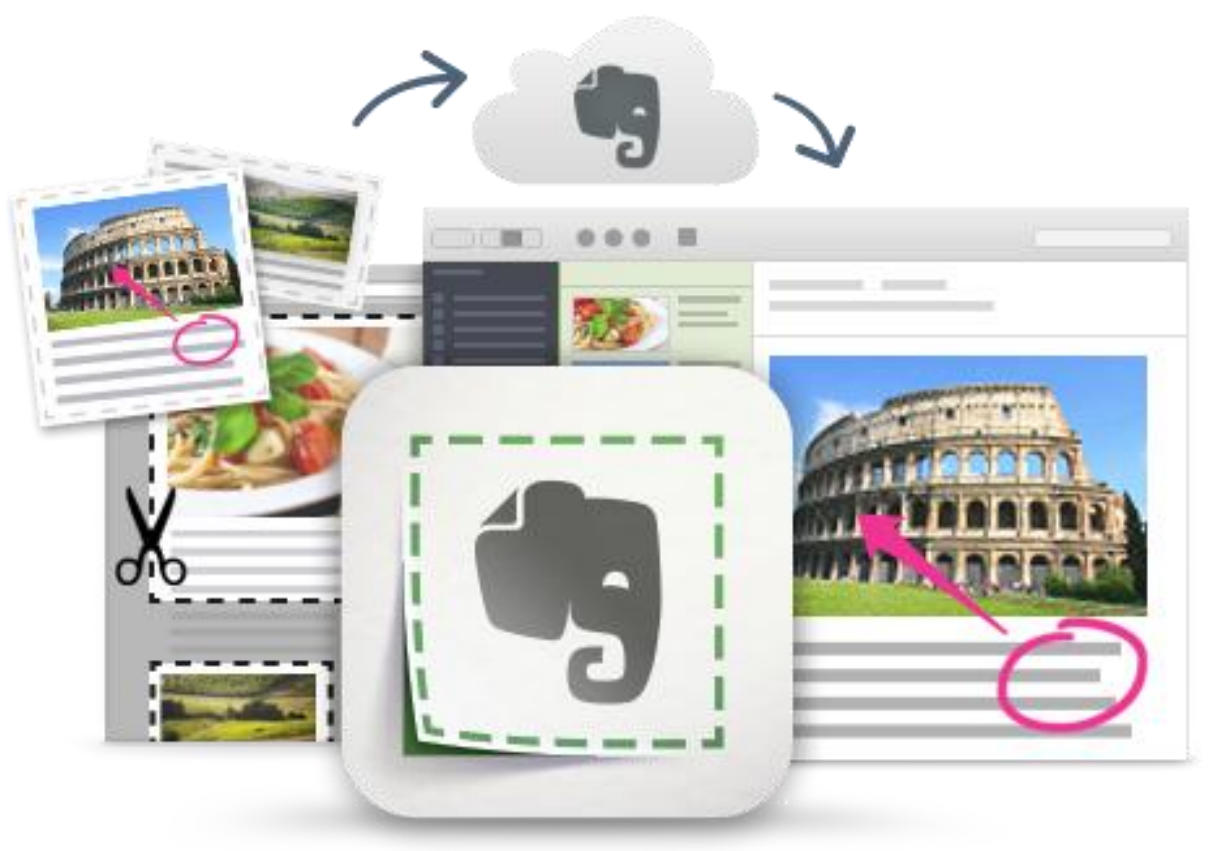

\section{Saját tapasztalatok}

Az iskolánkban bevezetett felhő alapú rendszernek évek kellettek, míg a hétköznapok részévé vált. Ma már teljesen természetes, hogy a tanárok a Google Apps Iskoláknak rendszerét használják az iskolai szervezési ügyek kezelésére. A közös megbeszélésre szánt szövegjavaslatok Google dokumentumokban születnek, a szülök ezen a rendszeren keresztül iratkoznak fel a tanárokkal történő beszélgetésekre, az iskola honlapján megjelenő naptár a Google naptárból tölti be a közelgő eseményeket. A tanárok a szülőknek írt üzeneteiket a központilag karbantartott levelező csoportokon keresztül küldik el.

Az iskola döntéshozó csoportjai a Trello segítségével követik nyomon a nagyobb projekteket és az éppen futó folyamatokat. Egészen egyértelmü, hogy csak akkor lehet ezeket az eszközöket beépíteni a szervezeti kultúrába, ha a tagok napi szinten használják a munkájukhoz. Az eseti továbbképzések csak rövid ideig tartó hatással bírtak, csak ott és az rögzült, amit valóban munkára fogtak.

\section{Tankerületi tapasztalatok}

A II. kerületi iskolák jól láthatóan rendezett elektronikus rendszerekkel müködnek, döntő többségükben müködik az e-mail használata és úgy tünik, hogy a dokumentumok kezelése is jól megy. Ami nagyon feltűnő, hogy egyetlen intézmény sem használ központi elektronikus naptárt, jóllehet a válaszadók $2 / 3$ része ezt hasznosnak tartaná. A másik ilyen ellátatlan terület a projektmanagement eszközök területe, itt csak egyetlen intézmény nyilatkozott úgy, hogy használ ilyen megoldást, de a válaszadók fele szívesen látna ilyet az intézményében.

A bevezetéssel kapcsolatban egyértelmüen látszik, hogy a vezetők szeretnék kipróbálni az őket érdeklő megoldásokat a bevezetés előtt, ezt minden vezető jól felfogott érdekének tekinthetjük.

A rendszerek bevezetését a válaszadók több, mint fele nehéznek ítéli, de nem mondható el, hogy összefüggést lehetne felfedezni a köznevelés rendszerében jelenleg zajló változások okozta nehézségek és a bevezetés nehézségei között, a válaszok ezen a téren teljesen megoszlottak. A vezetők egy kivételével szívesen foglalkoznának a jövőben ilyen fejlesztési kérdésekkel.

\section{Disszemináció}

A felhő alapú IKT rendszerek olyan lehetőséget biztosítanak az iskolák számára, amelynek 
segítségével nem csak lépést tarthatnak a fejlődő technológiával, hanem saját müködésüket is hatékonyabbá tehetik. Ehhez azonban változásra van szükség és az iskolai vezetésnek ezt a változást jól kell menedzselnie.

A vezetői nyitottság alapfeltétele az indulásnak, és az is megmutatkozik, hogy valódi sikert csak a változásmenedzsment fő pontjainak körültekintő és alapos végrehajtásával lehet elérni, ami nagyon erőforrásigényes munka.

Elsőnek a vezetőnek kell az új elveket megvalósítania. Le kell mondania a rutin adta magabiztosságról és vállalnia kell a tanulással, a változással járó kezdeti kellemetlenségeket. Új módon kell tudnia a helyzeteket kezelni, az ügyeket intézni, tudatosan kell leépítenie a régi megszokásokat. Ez az önfegyelem azonban egyrészt a változás érezhető örömét adja, másrészt megtanítja tisztelni a többiek problémáit, hiszen maga is átment ezeken és legyőzte őket. Ezzel példát is mutat.

És ha már sikerült önmagunkon ezt a változást meghoznunk, akkor olyan elvárásokat kell tudnunk megfogalmazni a folyamatokkal kapcsolatban, amelyek nem teljesíthetők a régi rutinokkal. Ha ugyanis nem érzi mindenki a bőrén, hogy az új rendszer használata elengedhetetlen a feladatok megoldásához, akkor a munkatársak nem fogják alkalmazni soha. Ha a régi rutin még mindig elfogadott, akkor természetes, hogy a változás nem fog bekövetkezni és minden ebbe fektetett erőforrást elpazaroltunk. Márpedig erőforrásaink szükösek.

A hazai köznevelésben fontos nem csak az igazgatókra hatni, hanem a tanárok közül azokat is elérni, akik ezen a téren a változás motorjai lehetnek. Célorientált, problémacentrikus képzésekkel segíteni kell azt a folyamatot, ami egy intézményben megteremti a változás kristályosodási gócát. 